DOI 10.22460/jpmi.v1i3.219-228

\title{
ANALISIS KEMAMPUAN PEMAHAMAN MATEMATIK SISWA SMP PADA MATERI SEGITIGA DAN SEGIEMPAT
}

\author{
Niva Ramadhani Putri ${ }^{1}$, Enni Astari Nursyahban ${ }^{2}$, Gida Kadarisma ${ }^{3}$, Euis Eti Rohaeti ${ }^{4}$ \\ 1,2,3,4 IKIP Siliwangi, Jl. Terusan Jenderal Sudirman, Cimahi, Jawa Barat, Indonesia \\ 1'nivaputri@gmail.com, ${ }^{2}$ astarienni@gmail.com, ${ }^{3}$ gidakadarisma@ikipsiliwangi.ac.id, \\ 3e2rht@yahoo.com
}

\begin{abstract}
The ability of mathematical understanding is an important goal in learning. the ability of mathematical understanding gives the understanding that the materials taught to students are not just as memorization. Students who have a mathematical understanding have a stronger foundation or foundation in learning mathematics. In this paper the ability of mathematical understanding of junior high school students is analyzed on triangular and rectangular materials. Triangle and quadrilateral material is one of the learning materials of junior high school students of even semester class. The method used in this research is qualitative descriptive, with limited subject that is nine students of SMP class VIII in one of junior high school of West Bandung, with classification of student ability high, medium, and low. The instrument used in this research is a mathematical comprehension test of seven questions and interview guidelines. The results obtained show that the mathematical understanding ability possessed by junior high school students in West Bandung is based on written test and the result of interview with students which is still relatively low.
\end{abstract}

Keywords: Mathematical understanding ability, Triangle and quadrilateral, Qualitative descriptive

\begin{abstract}
Abstrak
Kemampuan pemahaman matematik merupakan tujuan penting dalam pembelajaran. kemampuan pemahaman matematik memberikan pengertian bahwa materi-materi yang diajarkan kepada siswa bukan hanya sebagai hafalan. Siswa yang memiliki pemahaman matematik memiliki fondasi atau dasar yang lebih kokoh dalam belajar matematika. Pada artikel ini kemampuan pemahaman matematik siswa SMP dianalisis pada materi segitiga dan segiempat. Materi segitiga dan segiempat adalah salah satu materi pembelajaran siswa SMP kelas VII semester genap. Metode yang digunakan pada penelitian ini adalah kualitatif deskriptif, dengan subjek terbatas yaitu sembilan orang siswa SMP kelas VIII di salah satu SMP Kabupaten Bandung Barat, dengan klasifikasi siswa kemampuan tinggi, sedang, dan rendah. Instrumen yang digunakan dalam penelitian ini berupa tes kemampuan pemahaman matematik sebanyak tujuh soal dan pedoman wawancara. Hasil yang diperoleh menunjukkan bahwa kemampuan pemahaman matematik yang dimiliki siswa SMP di Kabupaten Bandung Barat berdasarkan pada tes tulis dan hasil wawancara dengan siswa yang masih tergolong rendah.
\end{abstract}

Kata Kunci: Kemampuan Pemahaman Matematik, Segitiga dan Segiempat, Kualitatif Deskriptif

How to cite: Putri, N. R., Nursyahban., E. A., Kadarisma, G., \& Rohaeti., E. E. (2018). Analisis Kemampuan Pemahaman Matematik Siswa SMP pada Materi Segitiga dan Segiempat. JPMI - Jurnal Pembelajaran Matematika Inovatif, 1 (2), 157-170. 
Matematika mempunyai sifat yang abstrak yang terdiri dari fakta, operasi atau relasi, konsep dan prinsip (Martunis, Ikhsan, \& Rizal, 2014). Sehingga untuk mempelajari matematika diperlukan kemampuan pemahaman yang baik. Menurut NCTM (Murizal, Yarman, \& Yerizon, 2012) terdapat tujuh indikator kemampuan pemahaman matematik, indikator tersebut yaitu siswa mampu : (1) Mendefinisikan konsep secara verbal dan tulisan; (2) Mengidentifikasi dan membuat contoh dan non-contoh; (3) Menggunakan model, diagram, dan simbol-simbol untuk mempresentasikan suatu konsep; (4) Mengubah suatu bentuk representasi ke bentuk lainnya; (5) Mengenal berbagai makna dan interpretasi konsep; (6) Mengidentifikasi sifat-sifat suatu konsep dan mengenal syarat yang menentukan suatu konsep; (7) Membandingkan dan membedakan konsep-konsep.

Kemampuan pemahaman matematik merupakan tujuan penting dalam pembelajaran. Kemampuan pemahaman matematik memberikan pengertian bahwa materi-materi yang diajarkan kepada siswa bukan hanya sebagai hafalan. Siswa yang memiliki pemahaman matematik memiliki fondasi atau dasar yang lebih kokoh dalam belajar matematika. Pentingnya kemampuan pemahaman matematik siswa dinyatakan oleh Nirmala (Purwosusilo, 2014) bahwa membangun pemahaman pada setiap kegiatan belajar matematika akan mengembangkan pengetahuan matematika yang dimiliki seseorang.

Berdasarkan data, penguasaan materi matematika siswa SMP di Indonesia terlihat dari hasil laporan The Trends International in Mathemtics and Science Study (TIMSS) pada tahun 1999, 2003, dan 2007 dan hasil tes Programme for International Student Assesment (PISA) pada tahun 2003 dan 2006 yang dikoordinir oleh Organization for Economic Coorperation and Development (OECD) mengungkapkan bahwa kemampuan matematik siswa Indonesia untuk soal-soal tidak rutn dan pemahaman konsep masih sangat lemah, namun relative baik dalam menyelesaikan soal-soal fakta dan prosedur (Suhandri, 2016). Salah satu pembelajaran matematika yang ada di SMP adalah memahami bangun-bangun geometri, unsur-unsur dan sifat-sifatnya, ukuran dan pengukurannya serta menggunakannya dalam pemecahan masalah (Mawaddah \& Ratih Maryanti, 2016). Pada konsep geometri, siswa tidak hanya dituntut untuk bisa membedakan bangun-bangun tersebut, tapi juga mengetahui keterkaitan antar konsepkonsep geometri melalui pemahaman mereka. Siswa harus memiliki kemampuan pemahaman konsep tersebut agar siswa dapat mengaplikasikan konsep secara tepat dan efisien dalam proses pembelajaran matematika.

Menyikapi hal tersebut maka peneliti perlu melakukan penelitian untuk mengetahui kemampuan pemahaman matematik siswa SMP di Kabupaten Bandung Barat dalam materi segitiga dan segiempat.

\section{METODE}

Penelitian ini merupakan penelitian kualitatif deskriptif, yang bertujuan untuk mendeskripsikan kemampuan pemahaman matematik pada materi segitiga dan segiempat, dengan subjek sembilan orang siswa, dengan klasifikasi siswa kemampuan tinggi, sedang, dan rendah. Untuk memperoleh data penelitian digunakan instrumen penelitian berupa tes kemampuan pemahaman matematik sebanyak tujuh soal dan pedoman wawancara. Siswa terlebih dahulu mengerjakan soal berupa tes kemampuan pemahaman matematik dengan waktu yang telah ditentukan, kemudian dilanjutkan dengan wawancara berkenaan dengan soal yang telah siswa kerjakan, maka data yang didapat dianalisis dengan rubrik penilaian tes kemampuan pemahaman matematik. 


\section{HASIL DAN PEMBAHASAN}

\section{Hasil}

Hasil analisis data kemampuan pemahaman matematik pada materi segitiga dan segiempat menyatakan bahwa skor yang didapat dari sembilan subjek berbeda sesuai klasifikasi kemampuannya. Berikut analisisnya :

\section{a. Analisis Soal Nomor 1}

\section{Indikator soal :}

Mengidentifikasi sifat-sifat suatu konsep dan mengenal syarat-syarat yang menentukan suatu konsep

Soal :

Perhatikan pernyataan-pernyataan dibawah ini!

a) Memiliki tiga buah sisi, dua diantaranya sama panjang

b) Memiliki tiga buah sisi yang sama panjang

c) Memiliki tiga buah sudut, sudut yang sehadap tidak sama besar

d) Memiliki tiga buah sudut, sudut yang sehadap sama besar

e) Memiliki satu buah sumbu simetri.

Berdasarkan pernyataan diatas mana sajakah yang merupakan sifat segitiga sama kaki? Jelaskan! Jawaban siswa I (level tinggi)

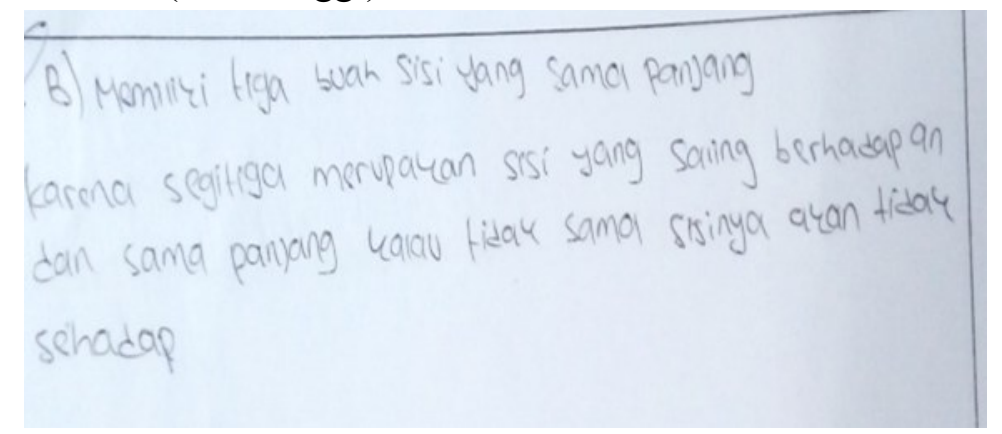

Gambar 1. Jawaban siswa I nomor 1.

Siswa I menjawab pertanyaan dengan tepat, hanya saja kurang lengkap, karena sifat d dan e adalah sifat segitiga samakaki. Berikut hasil wawancara dengan siswa I

$\mathrm{G}$ : "Apakah terdapat kesulitan dalam mengerjakan soal nomor 1?"

S : "Tidak, karena saya tahu bentuk segitiga sama kaki."

G : "Jawaban kamu benar, tapi coba ingat kembali, bukankah segitiga sama kaki juga memiliki dua sudut sehadap yang sama besar dan memiliki sebuah simetri?"

S : "Oh iya bu saya kira sifatnya cuma itu."

Jawaban siswa II (level sedang)

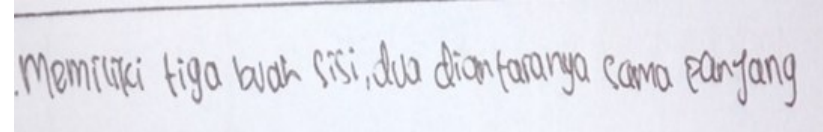

Gambar 2. Jawaban siswa II nomor 1.

Siswa II menjawab pertanyaan dengan benar, hanya saja kurang lengkap, karena sifat d dan e adalah sifat segitiga samakaki, dan lagi siswa II tidak menjelaskan mengapa sifat tersebut merupakan sifat segitiga sama kaki. Berikut hasil wawancara dengan siswa II 
G : "Apakah terdapat kesulitan dalam mengerjakan soal nomor 1?"

S : "Ada bu, aku ga ngerti apa itu sudut sehadap."

G : "Sudut sehadap itu sudut yang berhadapan, dan pada segitiga sama kaki sudut yang berhadapan pasti sama besar."

S : “Oh saya baru tau bu.” Jawaban siswa III (level rendah)

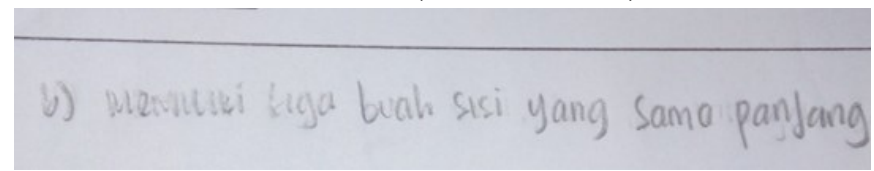

Gambar 3. Jawaban siswa III nomor 1.

Siswa III belum tepat dalam menjawab pertanyaan, siswa tersebut menyebutkan bahwa segitiga sama kaki memiliki semua sisi yang sama panjang. Berikut hasil wawancara dengan siswa III G : "Apakah terdapat kesulitan dalam mengerjakan soal nomor 1?"

$\mathrm{S}$ : "Ada bu, aku ga tau bentuk segitiga sama kaki kaya gimana bu."

\section{b. Analisis Soal Nomor 2}

Indikator soal :

Membuat contoh dan non contoh

Soal :

Perhatikan gambar berikut!

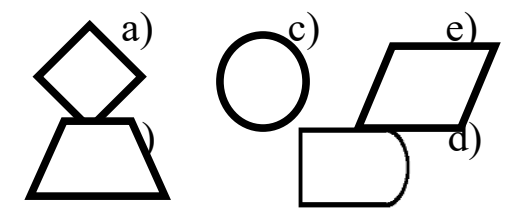

Manakah yang bukan termasuk macam-macam segiempat? Mengapa?

Jawaban siswa I (level tinggi)

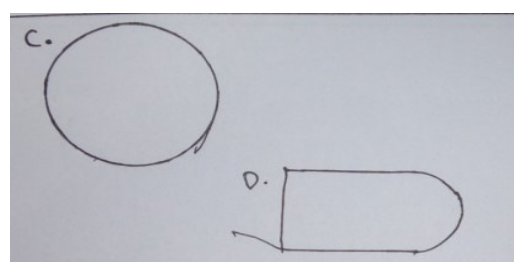

Gambar 4. Jawaban siswa I nomor 2.

Siswa I menjawab pertanyaan dengan tepat, hanya saja siswa I tidak menjelaskan mengapa bidang datar tersebut bukan merupakan segiempat. Berikut hasil wawancara dengan siswa I $\mathrm{G}$ : "Apakah terdapat kesulitan dalam mengerjakan soal nomor 2?"

S : "Tidak bu."

$\mathrm{G}$ : "Tapi kenapa kamu tidak memberikan penjelasan?"

$\mathrm{S}$ : "Saya tahu itu bukan segiempat bu, tapi saya kurang tahu gimana ngejelasinnya" Jawaban siswa II (level sedang)

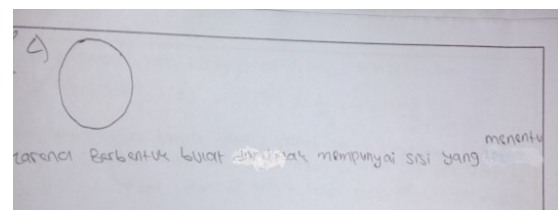

Gambar 5. Jawaban siswa II nomor 2. 
Siswa II menjawab pertanyaan dengan tepat dan terdapat penjelasan yang benar, hanya saja kurang lengkap karena gambar d juga merupakan gambar yang bukan contoh dari segiempat. Berikut hasil wawancara dengan siswa II

$\mathrm{G}$ : "Apakah terdapat kesulitan dalam mengerjakan soal nomor 2?"

S : "Tidak bu."

$\mathrm{G}$ : "Coba perhatikan kembali, segiempat itu adalah bidang datar yang memiliki empat buah sisi dan empat buah sudut, menurutmu, apakah gambar d merupakan segiempat?"

$\mathrm{S}$ : "Oh iya yah bu, aku pikir segiempat itu yang penting ada empat sisi."

Jawaban siswa III (level rendah)

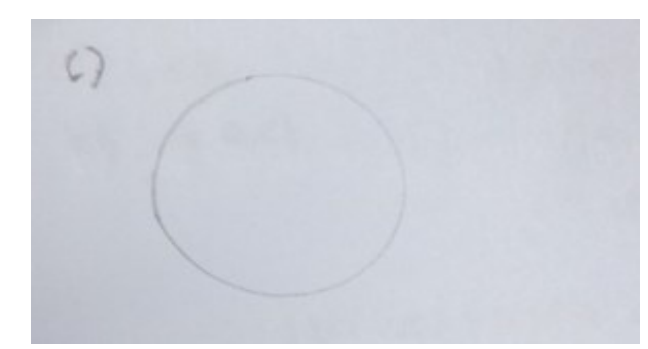

Gambar 6. Jawaban siswa III nomor 2.

Siswa III menjawab pertanyaan dengan benar tetapi tidak terdapat penjelasan dan kurang lengkap karena gambar d juga merupakan gambar yang bukan contoh dari segiempat. Berikut hasil wawancara dengan siswa III.

$\mathrm{G}$ : “Apakah terdapat kesulitan dalam mengerjakan soal nomor 2?”

S : "Tidak bu."

G : "Coba perhatikan kembali, segiempat itu adalah bidang datar yang memiliki empat buah sisi dan empat buah sudut, menurutmu, apakah gambar d merupakan segiempat?"

S : "Oh iya bu, aku lupa."

\section{c. Analisis Soal Nomor 3}

\section{Indikator soal :}

Mendefinisikan konsep secara verbal dan tulisan

Soal :

Dilihat dari panjang sisi dan besar sudutnya, segitiga sama kaki adalah?

Jawaban siswa I (level tinggi)

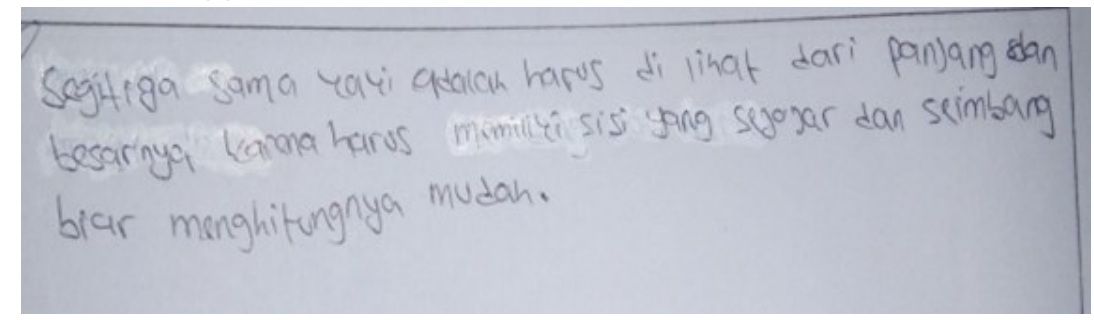

Gambar 7. Jawaban siswa I nomor 3.

Siswa I belum dapat menjawab pertanyaan dengan tepat. Berikut hasil wawancara dengan siswa I

G : "Apakah terdapat kesulitan dalam mengerjakan soal nomor 3?"

S : "Iya bu, saya ga tahu segitiga sama kaki itu apa." 
G : "Coba ingat kembali sifat-sifat segitiga sama kaki pada soal nomor 1, itulah pengertian segitiga sama kaki."

$\mathrm{S}$ : "Oh iya bu, padahal gampang ya bu"

Jawaban siswa II (level sedang)

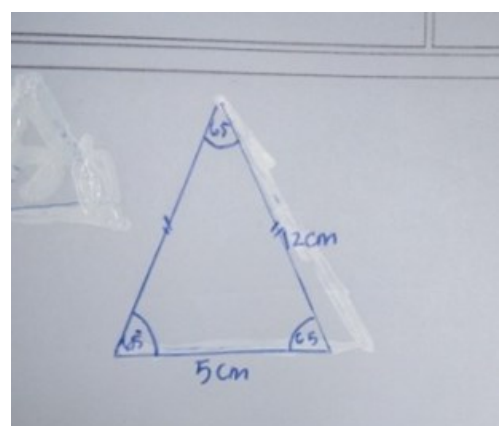

Gambar 8. Jawaban siswa II nomor 3.

Siswa II belum dapat menjawab soal dengan tepat. Berikut hasil wawancara dengan siswa II $\mathrm{G}$ : “Apakah terdapat kesulitan dalam mengerjakan soal nomor 3?”

$\mathrm{S}$ : "Iya bu, saya ga ngerti"

$\mathrm{G}$ : "Coba ingat kembali sifat-sifat segitiga sama kaki pada soal nomor 1, itulah pengertian segitiga sama kaki."

S : "Oh iya bu. Aku baru tau."

Jawaban siswa III (level rendah)

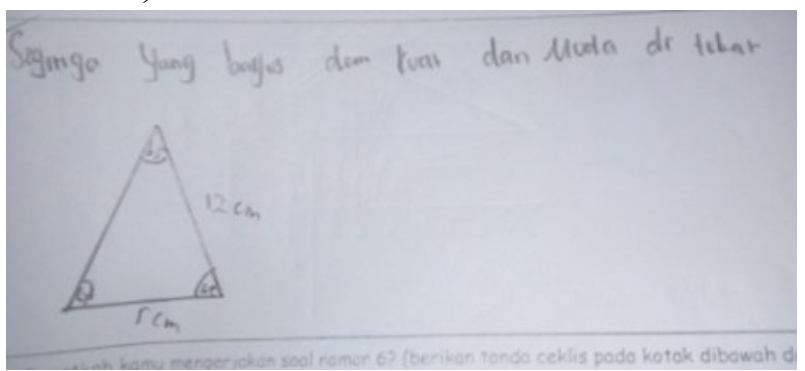

Gambar 9. Jawaban siswa III nomor 3.

Siswa III belum menajawab soal dengan tepat. Berikut hasil wawancara dengan siswa III

G : "Apakah terdapat kesulitan dalam mengerjakan soal nomor 3?"

$\mathrm{S}$ : "Iya bu, aku ga tau segitiga sama kaki, ini jawabannya asal."

$\mathrm{G}$ : "Coba ingat kembali sifat-sifat segitiga sama kaki pada soal nomor 1, itulah pengertian segitiga sama kaki."

S : "Oh iya bu, aku ngerti."

\section{d. Analisis Soal Nomor 4}

\section{Indikator soal :}

Mengubah suatu bentuk representasi ke bentuk representasi yang lain

Soal :

$\mathrm{ABCD}$ adalah suatu bangun dengan $\mathrm{A}(-2,4), \mathrm{B}(2,1), \mathrm{C}(8,4)$, dan $\mathrm{D}(2,7)$, sedangkan $\mathrm{E}$ adalah titik potong kedua diagonalnya. Bangun apakah yang terbentuk apabila ABCD dihubungkan? Tentukan koordinat titik E!

Jawaban siswa I (level tinggi) 


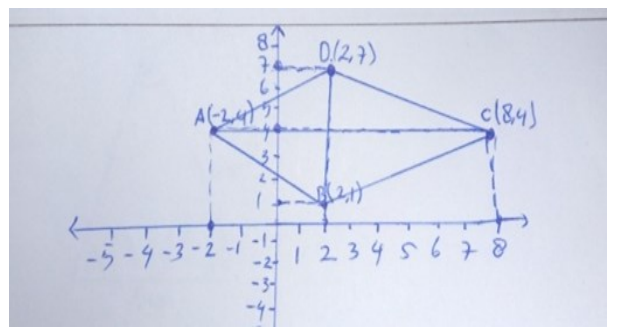

Gambar 10. Jawaban siswa I nomor 4.

Siswa I menjawab pertanyaan dengan tepat, bahwa gambar yang terbentuk dari 4 titik tersebut adalah laying-layang, hanya saja siswa tidak menyebutkan bidang apa yang terbentuk dan tidak menuliskan letak titik E pada koordinat tersebut. Berikut hasil wawancara dengan siswa I $\mathrm{G}$ : "Gambarmu ini sudah benar, hanya saja kenapa kamu tidak menentukan letak titik E?" S : "Lupa bu."

G : "Apa kamu tahu segiempat yang terbentuk pada bidang datar tersebut? Mengapa tidak kamu tulis pada lembar jawabanmu?"

S : "Layang-layang bu. Saya lupa bu."

Jawaban siswa II (level sedang)

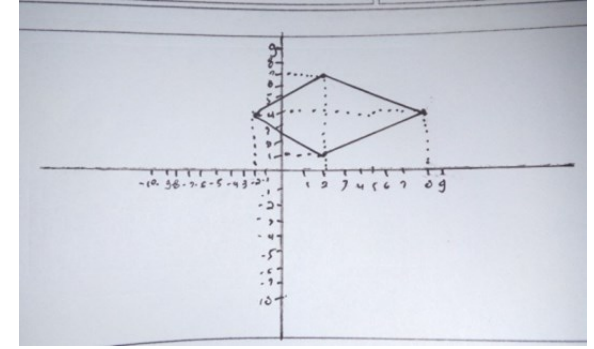

Gambar 11. Jawaban siswa II nomor 4.

Kesalahan jawaban siswa II sama dengan jawaban siswa I. Berikut hasil wawancara dengan siswa II

G : "Perhatikan gambarmu! Segiempat apa yang terbentuk? Mengapa tidak kamu tulis pada lembar jawabanmu?"

S : "Layang-layang bu, aku lupa."

Jawaban siswa III (level rendah)

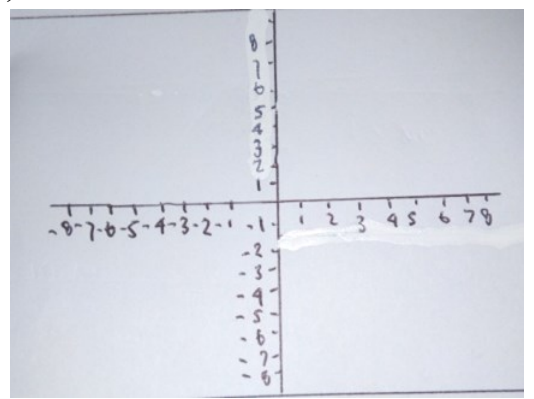

Gambar 12. Jawaban siswa III nomor 4.

Siswa III tidak dapat menyelesaikan permasalahan tersebut, ia hanya membuat koordinat pada lembar jawabannya. Berikut hasil wawancara dengan siswa III G : "Mengapa kamu hanya membuat koordinat?" 
S : "Aku ga bisa gambarnya bu, susah. Aku ga ngerti."

G : "Yang perlu kamu lakukan buat titik A, B, C, dan D pada koordinat tersebut, lalu tarik garis hingga membentuk segiempat."

S : "Oh iya bu aku inget."

\section{e. Analisis Soal Nomor 5}

Indikator soal :

Membandingkan dan membedakan konsep-konsep.

Soal :

Perhatikan gambar berikut!

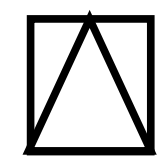

a) Tentukan Luas Persegi!

b) Tentukan Luas Segitiga!

c) Bandingkan jawabannya a dan b! Apa yang dapat kalian simpulkan dari perbandingan tersebut?

Jawaban siswa I (level tinggi)

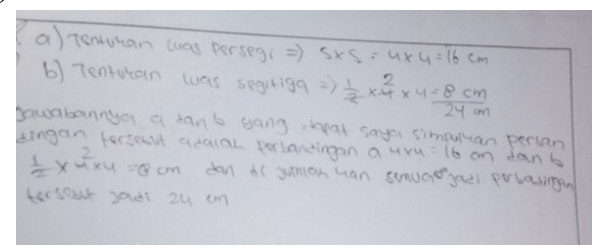

Gambar 13. Jawaban siswa I nomor 5.

Siswa I menjawab pertanyaan dengan benar, tetapi kurang lengkap. Ia dapat menentukan luas persegi dan luas segitiga dengan baik, tetapi ia belum memhami bahwa luas segitiga itu adalah setengahnya dari luas persegi. Berikut hasil wawancara dengan siswa I

$\mathrm{G}$ : "Bagaimana caramu menentukan luas persegi dan segitiga?"

$\mathrm{S}$ : "Ada rumusnya bu, luas persegi s $\mathrm{x}$, luas segitiga $\frac{1}{2} \mathrm{x}$ a $\mathrm{x}$ t, saya masih ingat"

$\mathrm{G}$ : “Coba kita bandingkan hasilnya, jika luas persegi $16 \mathrm{~cm}^{2}$ dan luas segitiga $8 \mathrm{~cm}^{2}$, maka luas segitiga itu adalah $\frac{1}{2}$ nya dari luas persegi, benar?"

$\mathrm{S}$ : "Benar bu, oh iya saya ngerti bu."

Jawaban siswa II (level sedang)

\section{Gambar 14. Jawaban siswa II nomor 5.}

Siswa II menjawab pertanyaan a dan b dengan benar, hanya saja kurang lengkap karena ia tidak menyelesaikan pertanyaan pada poin c. Berikut hasil wawancara dengan siswa II G : "Bagaimana kamu mendapatkan hasil seperti ini?" 
$\mathrm{S}$ : “Aku inget rumus luas persegi sama segitiga bu, terus tinggi segitiganya bakal sama kaya sisi persegi bu, tingginya 4 . Terus aku itung pake rumus luas persegi sama segitiga." "G : "Coba kita bandingkan hasilnya, jika luas persegi $16 \mathrm{~cm}^{2}$ dan luas segitiga $8 \mathrm{~cm}^{2}$, maka luas segitiga itu adalah $\frac{1}{2}$ nya dari luas persegi, benar?"

$\mathrm{S}$ : "Eh iya benar bu,aku baru ngerti."

Jawaban siswa III (level rendah)

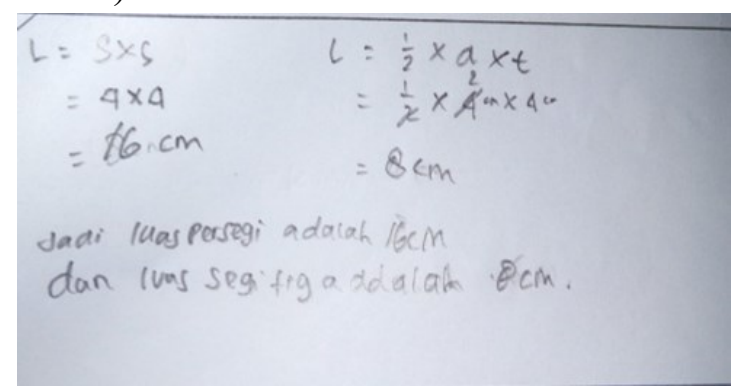

Gambar 15. Jawaban siswa III nomor 5.

Ketidak lengkapan jawaban siswa III sama seperti jawaban siswa II. Berikut hasil wawancara dengan siswa III

G : "Caramu mengerjakan soal a dan b sudah tepat, mengapa soal c tidak kamu kerjakan?"

$\mathrm{S}$ : "Aku ga ngerti bu, harus gimana ngerjainnya."

$\mathrm{G}$ : "Coba kamu bandingkan luas segitiga dan persegi, kamu akan memperoleh $6: 8$. kemudian kamu perkecil dan kamu akan mendapatkan hasil $1: 2$ atau $\frac{1}{2}$, maka perbandingan luas segitiga adalah $\frac{1}{2}$ nya dari luas persegi."

$\mathrm{S}$ : "Oh iya bu, aku baru ngerti."

\section{f. Analisis Soal Nomor 6}

Indikator soal :

Menggunakan model, diagram, dan simbol-simbol untuk mempresentasikan suatu konsep

Soal :

Sebuah kolam renang berbentuk persegi panjang mempunyai panjang $10 \mathrm{~m}$ dan lebar $6 \mathrm{~m}$. Di sekeliling kolam renang bagian luar akan dibuat jalan dengan jarak dari setiap sisi kolam renang tersebut adalah 1,5m. Jalan tersebut akan dipasang keramik berukuran $10 \mathrm{dm}$ x $10 \mathrm{dm}$. Jika harga setiap satu keramik Rp. 32.000,00. Berapakah biaya yang diperlukan untuk memasang keramik pada jalan tersebut? Gambarkan desain kolam renang yang dimaksud! Jawaban siswa I (level tinggi)

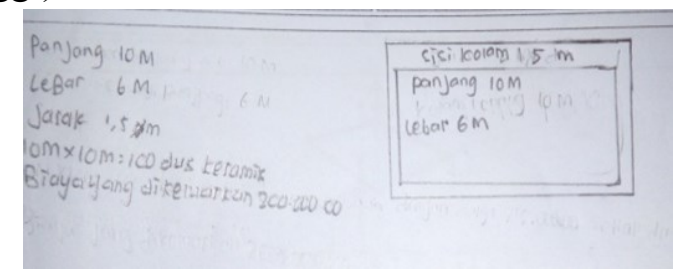

Gambar 16. Jawaban siswa I nomor 6.

Siswa I belum dapat menjawab pertanyaan dengan tepat. Berikut hasil wawancara dengan siswa I 
G : "Kesulitan apa yang kamu dapati dari soal nomor 6?"

$\mathrm{S}$ : "Saya ga paham apa yang harus saya hitung duluan bu"

Jawaban siswa II (level sedang)

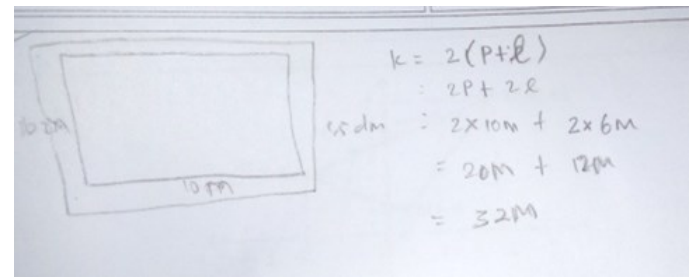

Gambar 17. Jawaban siswa II nomor 6.

Siswa II belum dapat menjawab pertanyaan dengan tepat, siswa II melakukan perhitungan mencari keliling untuk mendapatkan jawaban. Berikut hasil wawancara dengan siswa II $\mathrm{G}$ : "Kesulitan apa yang kamu dapati dari soal nomor 6?"

$\mathrm{S}$ : “Aku ga begitu ngerti apa yang harus aku cari bu. Karena ada kata sekeliling jadi jadi aku cari keliling persegi itu aja."

G : "Coba baca dan perhatikan kembali, yang harus kamu cari adalah luas jalan yang akan dikeramik bukan kelilingnya, lalu hasil tersebut dibagi dengan ukuran luas keramik dan dikalikan dengan harga satu buah keramik."

S : "Iya bu, aku ngerti sekarang, nanti aku coba lagi."

Jawaban siswa III (level rendah)

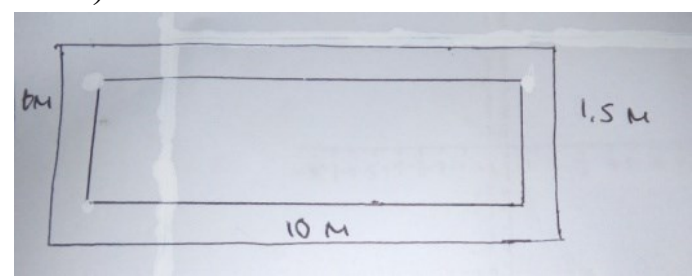

Gambar 18. Jawaban siswa III nomor 6.

Siswa III belum dapat mengerjakan soal ini dengan tepat, siswa III hanya membuat sketsa gambar kolam dan sketsanya pun belum tepat. Berikut hasil wawancara dengan siswa III G : “Apa kesulitan pada soal nomor 6?"

$\mathrm{S}$ : “Aku ga ngerti apa yang ditanyain bu, apa yang harus aku itung, aku ga ngerti. Soalnya terlalu panjang."

\section{g. Analisis Soal Nomor 7}

Indikator soal :

Mengenal berbagai makna dan interpretasi konsep

Soal :

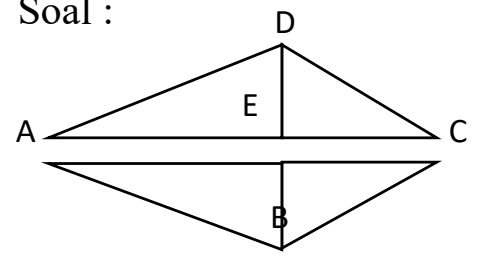

a) Sebutkan segitiga-segitiga yang tumpul

b) Sebutkan segitiga-segitiga yang lancip

c) Sebutkan segitiga-segitiga yang siku-siku

Jawaban siswa I (level tinggi) 


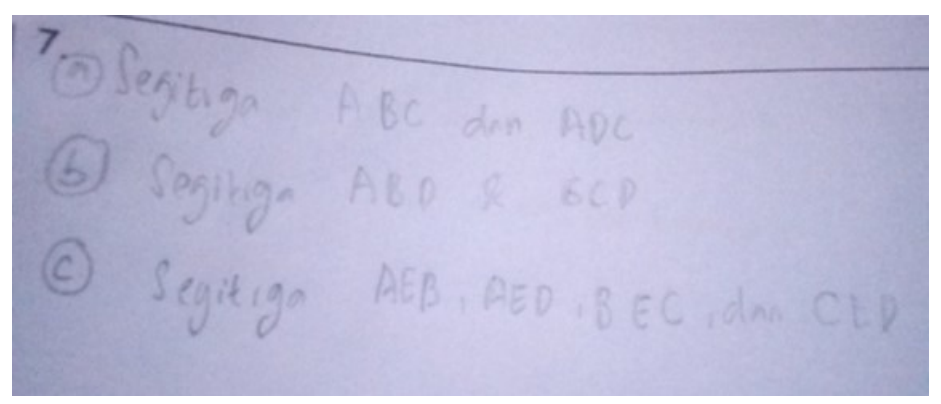

Gambar 19. Jawaban siswa I nomor 7.

Siswa I menjawab pertanyaan dengan tepat, ia mampu membedakan segitiga siku-siku, segitiga lancip, dan segitiga tumpul. Berikut hasil wawancara dengan siswa I

G : "Bagaimana caramu membedakan segitiga siku-siku, lancip, can tumpul?"

S : "Saya ingat dulu bu pernah belajar sudut, kalau siku-siku harus kaya sikut bentuknya, yang lancip tajem kaya pensil, kalau yang tumpul gitu ga tajem.”

Jawaban siswa II (level sedang)

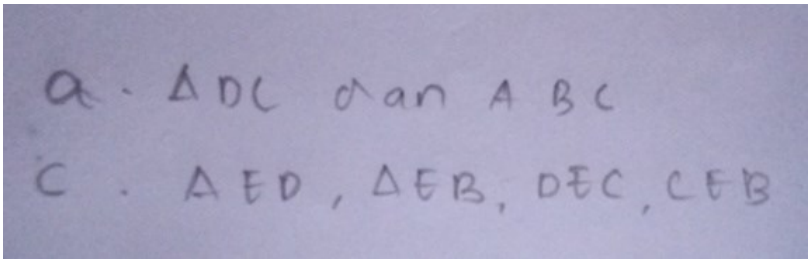

Gambar 20. Jawaban siswa II nomor 7.

Siswa II menjawab pertanyaan dengan tepat tetapi tidak lengkap. Berikut hasil wawancara dengan siswa II

G : "Kenapa kamu tidak jawab pertanyaan yang segitiga tumpul?"

$\mathrm{S}$ : "Aku ga ngerti bu yang tumpul yang gimana. Jadi ga aku isi."

Jawaban siswa III (level rendah)

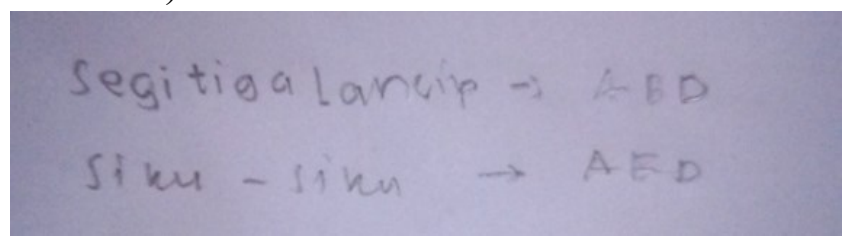

Gambar 21. Jawaban siswa III nomor 7.

Siswa III menjawab pertanyaan dengan benar tetapi tidak lengkap. Berikut hasil wawancara dengan siswa III

G : "Apa terdapat kesulitan pada soal nomor 7?"

$\mathrm{S}$ : “Ada bu, aku Cuma inget segitiga siku-siku, yang lainnya lupa."

Subjek dengan level tinggi dari tujuh indikator tes kemampuan pemahaman matematik memenuhi dua indikator lengkap dan tepat, tiga indikator kurang lengkap, serta dua indikator belum tepat.

Subjek dengan level sedang dari tujuh indikator tes kemampuan pemahaman matematik memenuhi lima indikator kurang lengkap, dan dua indikator belum tepat.

Subjek dengan level rendah dari tujuh indikator tes kemampuan pemahaman matematik memenuhi empay indikator kurang lengkap, dan tiga indikator belum tepat. 
Dengan demikian, sesuai dengan hasil analisis dari sample siswa SMP di Kabupaten Bandung Barat dengan klasifikasi level tinggi, sedang dan rendah menunjukkan bahwa rat-rata tingkat kemampuan pemahaman matematik masih tergolong rendah.

\section{Pembahasan}

Tes kemampuan pemahaman matematik sebanyak 7 soal diberikan kepada 9 siswa masingmasing sampel dari siswa kemampuan rendah, sedang dan tinggi. Dari hasil analisis data diperoleh bahwa siswa dengan kemampuan tinggi, sedang dan rendah ketiganya mengalami kesulitan dalam mengerjakan soal pemahaman matematika, hanya saja kuantitas siswa pada level kemampuan tinggi bisa mengerjakan sebagian pada indikator pemahaman matematika. Berdasarkan analisis data, pemahaman matematik dari setiap klasifikasi siswa berkemampuan rendah, sedang dan tinggi perlu ditingkatkan hal ini mengingat segitiga dan segiempat merupakan konsep dasar yang perlu dikuasai siswa dalam mempelajari konsep pada materi lain yang lebih sulit, hal ini sejalan dengan (Syifaya, 2012) yang menyatakan materi segitiga dan segiempat merupakan salah satu konsep dalam mata pelajaran matematika di SMP/MTs yang sangat fundamental dan mempunyai keterkaitan yang berkelanjutan dengan konsep matematika lainnya.

Berdasarkan wawancara dan observasi yang dilakukan oleh peneliti kesukaran dalam mengerjakan soal pemahaman matematik dikarenakan siswa hanya menghafal rumus dan pembelajaran yang dibawakan oleh guru masih prosedural, hal ini sejalan dengan hasil penelitian (Yezita, Rosha, \& Yerizon, 2012) yang menyatakan Menurut siswa materi segitiga dan segiempat masih sulit mereka pahami. Hal ini disebabkan karena pada pembelajaran segitiga dan segiempat di sekolah dasar mereka cenderung menghapal rumus tanpa tahu dari mana rumus tersebut diperoleh. Mereka memperoleh pengetahuan dari penjelasan gurutanpa terlibat langsung dalam pembelajaran. Hal ini mengakibatkan pengetahuan yang mereka peroleh tidak bertahan lama dalam ingatan mereka. Dari pemaparan-pemaparan diatas, jelas kemampuan pemahaman matematik siswa perlu ditingkatkan dengan pembelajaran yang kreatif dan inovatif yang dibawakan oleh guru.

\section{KESIMPULAN}

Berdasaran pada hasil dan pembahasan, dapat disimpulan beberapa kesalahan siswa dalam menjawab soal, yaitu :

a. Kesalahan dalam menafsirkan solusi karena tidak memahami pertanyaan yang diberikan;

b. Kesulitan dalam menggambarkan atau menyajikan sketsa untuk menyelesaikan pertanyaan; serta

c. Kurangnya pemahaman dalam konsep-konsep matematika.

Dengan begitu, sesuai dengan hasil analisis dari sampel siswa SMP di Kabupaten Bandung Barat dengan klasifikasi level tinggi, sedang, dan rendah menunjukan rata-rata tingkat kemampuan pemahaman matematik masih tergolong rendah.

\section{DAFTAR PUSTAKA}

Martunis, Ikhsan, M., \& Rizal, S. (2014). Meningkatkan Kemampuan Pemahaman dan 
Komunikasi Matematis Siswa Sekolah Menengah Atas melalui Model Pembelajaran Generatif. Jurnal Didaktik Matematika, 1(2), 75-84.

Mawaddah, S., \& Ratih Maryanti. (2016). Kemampuan Pemahaman Konsep Matematis Siswa SMP dalam Pembelajaran Menggunakan Model Penemuan Terbimbing (Discovery Learning). Edu-Mat Jurnal Pendidikan Matematika, 4(April), 76-85.

Murizal, A., Yarman, \& Yerizon. (2012). Pemahaman Konsep Matematis dan Model Pembelajaran Quantum Teaching. Jurnal Pendidikan Matematika, 1(1), 19-23.

Purwosusilo. (2014). Peningkatan Kemampuan Pemahaman Dan Pemecahan Masalah Matematik Siswa SMK Melalui Strategi Pembelajaran React (Studi Eksperimen Di SMK Negeri 52 Jakarta). Jurnal Pendidikan Dan Keguruan, 1(2), 30-40.

Suhandri. (2016). Meningkatkan Kemampuan Pemahaman Matematis Siswa SMP/MTs dengan Menggunakan Strategi Konflik Kognitif. Jurnal Penelitian Dan Pembelajaran Matematika, 9(2), 240-249.

Syifaya, N. (2012). Penerapan Pembelajaran Model ARIAS (Assurance, Relevance, Interest, Assessment, dan Satisfaction) melalui Pemberian Resitasi Di Akhir KBM dalam Meningkatkan Pemahaman Matematika Siswa Pada Pokok Bahasan Segitiga dan Segiempat" (Penelitian Eksperimen di MT. UIN Sunan Gunung Djati.

Yezita, E., Rosha, M., \& Yerizon. (2012). Mengkonstruksi Pengetahuan Siswa pada Materi Segitiga dan Segiempat Menggunakan Bahan Ajar Interaktif Matematika Berbasis Konstruktivisme. Jurnal Pendidikan Matematika, 1(1), 54-59. 
